IRA-International Journal of Education \& Multidisciplinary Studies ISSN 2455-2526; Vol.06, Issue 01 (2017)

Pg. no. 31-55

Institute of Research Advances http://research-advances.org/index.php/IJEMS

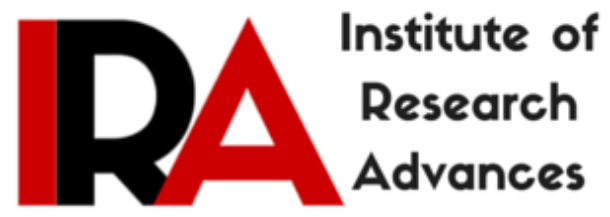

\title{
Individual and Contextual Factors Associated with Married Women's HIV Status in India, National Family Health Survey- 3
}

\author{
Tapati Dutta ${ }^{1}$, S K Singh ${ }^{2}$, Subrato K Mondal ${ }^{3}$, Lopamudra Paul ${ }^{4}$ \\ ${ }^{1} \mathrm{PhD}$ Scholar, Indiana University, USA \\ ${ }^{2}$ Professor, International Institute for Population Sciences, India \\ ${ }^{3}$ Evaluation Specialist, Development Evaluation Society of India, India \\ ${ }^{4} \mathrm{M} \& \mathrm{E}$ Specialist at The UNION
}

Type of Review: Peer Reviewed.

DOI: http://dx.doi.org/10.21013/jems.v6.n1.p3

\section{How to cite this paper:}

Dutta, T., Singh, S., Mondal, S., \& Paul, L. (2017). Individual and Contextual Factors Associated with Married Women's HIV Status in India, National Family Health Survey3. IRA International Journal of Education and Multidisciplinary Studies (ISSN 24552526), 6(1), 31-55. doi:http://dx.doi.org/10.21013/jems.v6.n1.p3

(C) Institute of Research Advances

(c) EY-NC

This work is licensed under a Creative Commons Attribution-Non Commercial 4.0 International License subject to proper citation to the publication source of the work.

Disclaimer: The scholarly papers as reviewed and published by the Institute of Research Advances (IRA) are the views and opinions of their respective authors and are not the views or opinions of the IRA. The IRA disclaims of any harm or loss caused due to the published content to any party. 


\begin{abstract}
There are increasing concerns related to feminization of human immunodeficiency virus (HIV) in India especially its showing up among married women. Nuances of HIV related risk and vulnerability are myriad among them (married women) who are either oblivious to their partner's risk behavior, unaware of their partners' or own sero-status and often cannot negotiate safer sex. Dearth of evidence on HIV prevention programs indicating gendered outcomes further obscures the situation. National Family Health Survey- 3 data of India were reviewed to identify individual and familial correlates in their marital families, which might be associated with the HIV status among married women in India. Bivariate and regression methods were used. Findings indicated key factors which add to the vulnerability of married women's risk-proneness to contract HIV. It calls for more socio-behavioral and implementation research addressing HIV transmission and prevention among married women in India, where typically the thrust has been mostly on HIV high risk populations like female sex workers, injecting drug users and men who have sex with men.
\end{abstract}

Keywords - Married women, HIV, India

\title{
INTRODUCTION
}

Women are at increased risk for human immunodeficiency virus (HIV) on account of their biological vulnerabilities, own sexual behavior and if they are partners of men belonging to most at risk population groups, that is; men with multiple sexual partners, men who are clients of sex workers, those men who have sex with men (MSM) and injecting drug users (IDUs) and those who practice high-risk sexual behaviors (UNAIDS, 2009). In marriage or intimate partner relations, socio-cultural factors such as gender inequities, cultural norms clubbed with limited economic and social autonomy makes women more susceptible to HIV (UNAIDS, 2000). Literature reveals that younger women are more vulnerable than their male counterparts to HIV and Acquired Immunodeficiency Syndrome (AIDS) due to biological, social, cultural and economic reasons and most new infections occur among young women between the ages of 15-24 (UNAIDS, 2006). Moreover, the consequences of living with HIV could differ dramatically for women and men (ICW News Issue 19, ICW, 2000; ICW, 2001).

National estimates in India show that 39 percent of all the HIV infections is among women (NACO, 2012-13). While the HIV prevalence rate in India is low (<1percent) and has a declining trend, the gender gap in new HIV infections is continuously narrowing down (NACO, 2008; UNAIDS, 2010). Over the past decade there was a noted shift in the proportion of HIV-positive women in India with male to female ratio of 5:1 in 1994 to more recent estimations of 1.2:1 (Hawkes et.al., 2002) and 1.7:1 (UNAIDS, 2004b). HIV data among ante-natal care (ANC) clinic attendees was approximately 140,000 deliveries to HIV-positive women, which reflected 0.5 percent HIV prevalence among married women (NACO, 2004).

Previous literature showed that the infection rates are increasing, more rapidly among women particularly among them whose only 'high-risk behavior' was being married (Gangakhedkar et. al., 1997; Bhattacharya, 2004, Newmann et.al., 2006; Mehendale et. al. 2007). Other in-country studies corroborated similar findings and showed that over 90 percent of the infected women acquired HIV from their husbands or their intimate sexual partners (USAID, 2010). Reiterating, a report from southern India found that 95 percent of HIV-infected women were currently or previously married, and 88 percent reported a history of monogamy, implying that most of the women were infected by their husbands (Newman et al., 2000). Similar trends were seen from data of antenatal clinics where 87 percent housewives were tested HIV-positive (NACO, 2001-2004). Other studies from diverse regional settings in India have also documented that sero-negative female partners in HIV discordant relationships are at increased risk of acquiring HIV and that a substantial number of new HIV infections occurred within stable monogamous relationships (Gangakhedkar et.al., 1997; UNAIDS / UNFPA / UNIFEM, 2004; UNAIDS, 2006). Studies also caution that while cent percent women disclosed their sero-status to their 
husbands, it was a much lesser percentile of husbands who disclosed their sero-positivity to their wives (Population Council 2007). Of concern are results from projection studies which indicated that the number of married, heterosexual Indian women infected with HIV/AIDS was likely to increase (Chatterjee et.al. 2006). Population-based studies indicated that between 55 and 100 percent of evermarried women reported one or more symptoms related to reproductive morbidities and Sexually Transmitted Infections (STIs), which in turn increased their risk to HIV (Bhatia et.al. 1995; Rodrigues et. al., 1995; Koenig et. al.1998; Prasad et. al., 1999; Oomman, 2000; Garg et.al., 2002; Kambo et. al., 2004; Reynolds et. al.2006).

HIV and related research in the country has focused largely on high risk populations such as female sex workers, MSM, IDUs, and truck drivers (Basu et.al, 2004). While studies by Maman et.al. (2000) presented a relatively small size of the body of literature describing intersections between HIV and violence against women, other studies from India assessing the prevalence of and risk factors for HIV and domestic violence have mostly focused on rural populations (Rao, 1997; Jejeebhoy et.al.1997; Jejeebhoy, 1998). Again, few studies have evaluated rates of sexual violence in the household an increasingly important precursor to contract HIV (Koenig et al., 2004). In the Indian patriarchal context women are less likely to negotiate condom use with their husbands and are often in the dilemma of choosing between disease prevention and the fulfillment of reproductive role (Mane et. al., 1994; Santhya et.al., 2007). HIV transmission risk to the latter is even exacerbated through husbands who might have unprotected sex outside of the marriage with multiple partners or sex workers (Srikanth et. al.1997; Solomon et.al. 1998; Bhattacharya, 2004).

With a high proportion of married women who are HIV positive in the country, added to the gendered vulnerabilities and observing the limitations in conclusive literature, it is pertinent to understand such determinants; which are 'features of' and 'pathways to' affecting HIV outcomes among married women in India.

Our study proceeded with the specific objectives to analyze if there was any association between comprehensive knowledge of HIV and HIV related risk behavior, to understand the impact of domestic violence and women's empowerment on HIV status of women and to identify factors which affected risk to HIV infection among married women in India.

\section{DATA and METHODS}

Survey data from the third round of the National Family Health Survey (NFHS -3, (2005-2006), India, which collected demographic, socioeconomic and behavioral data was considered for our study. The survey covered 99 percent of India's population collecting information from a nationally representative sample of 109,041 households covering 124,385 women aged 15-49 years and 74,369 men aged 15-54 years. In each state, the rural sample was selected in two stages, whereas a three-stage procedure was followed in urban areas. NFHS-3, for the first time, provided assessments of HIV prevalence among general population (adult women and men) at the national level for Uttar Pradesh and for five HIV high prevalence States of India (Andhra Pradesh, Karnataka, Maharashtra, Manipur and Tamil Nadu). 102,946 participants of whom 52,853 were women were tested for HIV.

For the current study, we merged the individual women and HIV files. The analytical sample consisted of 37,781 women after excluding the subjects with missing values and restricting the sample to those women who were sexually experienced or exposed and provided data on their marital status. We used descriptive statistics to assess the socio-economic and behavioral correlates of HIV related risk behavior. The dependent variable was dichotomous indicating, "yes" (1) for having HIV and "no" (0) for not having HIV. Both 'all women' and 'only married women' who could be linked to their husbands have been considered. The latter group provided additional information about couple relationship variables. 
Women's individual level variables considered were: women's current age, her age at marriage, education, exposure to media, religion, caste and wealth. Family level indicators were type of family and behavioral and contextual factors were husband's alcoholism, migration status of husband, gender role attitude of husband, perceived reproductive rights by women, control of women's sexuality, domestic violence, woman's mobility and wife beating attitude of husband.

A dummy variable was created for 'sexual autonomy', with binomial answers- Yes= 1 or No-0. Sexual right/autonomy among married women was described based on 3 questions asked in NFHS-3: (1) Right to decline sex with partner/husband due to the later having STI or indulging in sex with other women and (2) Right to decline sex with partner/husband because the respondent is feeling tired or not in mood.

A dummy variable was created for 'women's empowerment', with binomial answers- Yes $=1$ or $\mathrm{No}=0$. Women's empowerment was determined based on responses to three questions: 1) Decisions regarding spending money and husband's earning, 2) Making large household purchases and purchases of daily need, 3) Having final say on own health care and 4) Independent decision making capacity to visit her natal family. A 'Yes' to any one question yielded a 'Yes' to women's empowerment'.

We categorized comprehensive HIV knowledge as $1=$ No knowledge, $2=$ Low knowledge - knowing anything between 1-6 ways to prevent or spreading HIV, 3= Medium Knowledge - knowing anything between 7-14 ways to prevent or spreading HIV and 4= High knowledge - knowing 15 and more ways to prevent or spreading HIV. While almost half of the women reported 'no knowledge of HIV'.

To understand the effect of socio-economic factors on comprehensive knowledge of HIV, we carried out Multiple Classification Analysis (MCA). We used Eta statistics to show relationship between predictor and the independent variable and Beta statistics to measure the relationship between predictor and the independent variable. Subsequently bi-variate analysis was used to analyze adjusted effects of individual, familial and contextual determinants of HIV related risk behaviors.

Logistic regression with three different models was carried out to understand impact of individual factors and factors in combination on HIV status among married women in India. Model-1 considered impact of domestic violence on HIV; Model-2 explored effect of socio-economic status and women's autonomy on her HIV status and Model-3 explored the impact of three aspects in combination, domestic violence, socio-economic status and women's autonomy, on HIV status among married women in India, while controlling for other factors.

\section{FINDINGS}

Bivariate findings (Table 1) revealed that the burden of the epidemic was mostly borne by relatively younger women in their prime reproductive ages. Bi-variate analysis (Table-1) showed 0.19 percent prevalence of HIV among married women in India. A clear regional clustering of HIV prevalence was seen in Southern (Andhra Pradesh, Karnataka and Tamil Nadu), Northern (Delhi, J\&K and Himachal Pradesh), Western (Gujarat and Maharashtra) and North-Eastern states (Assam and Manipur). Consistent with HIV prevalence rates, high prevalence States (North East, especially Assam and Manipur (1.43 percent) and South Maharashtra, Andhra Pradesh, Tamil Nadu and Karnataka) showed higher percentile of HIV positive married women. Higher rates of HIV among married women were also seen in otherwise low prevalence States like Himachal Pradesh (0.42 percent) and Delhi ( 0.41 percent), building on the emerging concern for a rising trend of the epidemic in certain low prevalence States.

HIV prevalence by background characteristics are mentioned in Table 2. Prevalence was highest among married women who were Hindus, women who belonged to richer sections of the society and those aged between 30-34 years indicating higher HIV rates among married middle-aged married women. HIV prevalence was the lowest among married women in the richest and wealth quintile women, among 
Muslim women and women with eleven and more years of schooling. Prevalence of HIV was significantly higher among urban women than rural. It was also higher among women who had experienced forced sexual act and those women who had an alcoholic husband.

On education attainment, there was no specific result which could highlight the impact of each additional year of education on the married woman's HIV status.

Table 3 depicts the comprehensive knowledge of HIV among currently married women by background characteristics 31 percent with 'low knowledge' and 'high knowledge' was only among 0.7 percent women. Level of comprehensive knowledge HIV among currently married women by their background characteristics revealed that 59.7 percent women in rural areas did not have any knowledge of HIV, whereas 27.3 percent demonstrated 'low knowledge' on HIV. Almost 40.5 percent women in urban areas possessed low knowledge on HIV and 26.4 percent reported as no knowledge of HIV infection.

Among women from different religions there were some variations in the pattern of comprehensive knowledge, 49.8 percent of Hindus reported not having any knowledge on HIV whereas 28.6 percent Christians and others had medium level knowledge on HIV. A gross lack of knowledge of HIV was reported among women who were Scheduled Tribes (ST), whereas 17.5 percent women from general class had medium level of knowledge of HIV.

Literacy was highly associated with HIV knowledge. Almost three-fourth illiterate women did not have any knowledge of HIV or HIV prevention. Another 20 percent illiterate women had very little knowledge. Only 4.6 percent of illiterate women reported medium level of knowledge of HIV. Similarly, maximum percentage ( 83 percent) of women from the poorest quintile had 'no knowledge' of HIV. Lack of knowledge was stark among younger and older women compared to other age groups. Media exposure came as a very important factor on imparting HIV knowledge, and 86.1 percent of those women who did not have any knowledge of HIV, did not have any exposure to media either. There was marginal difference among women with or without experience of domestic violence and their levels of knowledge on HIV. Almost 60 percent women who experienced any domestic violence had knowledge of HIV. Similar pattern was also observed with number of sexual partners, wherein women in multiple partner relationships, were more wary and knowledgeable about HIV. There was marginal difference on low, medium, high and no knowledge of HIV among women having sexual rights versus those who did not have those rights. Comparative higher disadvantage of knowledge was there among the socially deprived rural and tribal women, reflecting on multiple deprivation and vicious cycle to HIV vulnerability. HIV prevention awareness was more among those with high risk behaviors.

Multiple classification analysis (Table 4) showed HIV knowledge was higher among urban women than rural but the difference narrowed after controlling for other factors. Knowledge level was the lowest among Hindus who knew three ways of transmission or prevention of HIV infection, after controlling for other background characteristics. Looking at unadjusted values among the caste groups HIV knowledge was lowest among SC women, though the difference reduced once the other factors were controlled for. . Women's employment status, media exposure, domestic violence and women's empowerment showed difference in the knowledge level but after adjusting for all other factors the net effect of each of them on HIV knowledge level became marginal.

Findings showed higher women's autonomy with a national aggregate around 80-85 percent, and almost all states, save Meghalaya and Assam, portrayed lower women's autonomy than the national average ( $<80$ percent). About half of the women respondents projected artifacts of empowerment with highest women's empowerment in Manipur (84.3 percent) and the least in Assam (26.7 percent).

Analyzing with background variables showed age at consummation of marriage, consistent condom use, number of sexual partners, women having higher autonomy, empowerment, any mass media exposure and 
states with or without out-migration had marginal difference across the categories. Findings also reinforced that domestic violence had significant impact of prevalence of HIV among married women in India. (Table-2).

Almost a quarter of married women (26.3 percent) reported being exposed to domestic violence, with Bihar having 39.8 percent women and Himachal Pradesh with a low of 4.2 percent women who reported domestic violence. Coercive sex revealed a national average of 2.8 percent and 34 percent women who had an alcoholic husband. Coercive sex was highest in Rajasthan (6.6 percent), while women in Manipur had the highest number of alcoholic partners (61.1 percent). Arunachal Pradesh, Manipur, Tripura and Assam; and Uttar Pradesh, Bihar, Rajasthan, Andhra Pradesh and Tamil Nadu had a sizeable percentile women who reported some form of domestic violence. Coercion in sex was particularly higher in the north eastern States.

Logistic regression results are highlighted in Table 5. Model-1 showed that place of residence, husband's drinking alcohol and mass media exposure has significant effect on HIV prevalence. Women living in urban areas are more likely get HIV infection than rural women. In addition, women who belong to SC community, and between 30-34 years had significantly higher risk on HIV infection than younger women (15-19 years) who belong to non- Schedule Caste /Schedule Tribe/Other Backward Classes. Likelihood of HIV infection was significantly higher among women whose partner's drinks alcohol and women from richer sections rather than women from the poorest wealth quintile. Risk to contract HIV was lower among women who had mass media exposure than among them who did not have similar exposure. Sexual behavior acted as an intervening variable between HIV and marital relationship. Marriage was likely to be more protective if both partners were in a singular-partner relationship.

Model-2 explained the effect of background variables after controlling for women's empowerment on HIV infection. Results showed that women's empowerment did not have any significant effect of HIV infection. This model did not control for domestic violence and partner's alcoholism with other factors to understand the effect of women's empowerment on HIV infection. But women who had multiple partners showed more likelihood to contract HIV, than monogamous women.

Model-3 explained impacts of all factors on HIV infection among currently married women after controlling for domestic violence and women's empowerment. It showed that urban women, richer women and women belonging to SC category had a higher risk of contracting HIV infection. Women who had media exposure were less likely get HIV infection. Husband's alcoholism was an important predictor for HIV infection among wife even after controlling for all other factors. Literacy, consistence condom use, domestic violence, coercive sex did not show any significant impact on HIV infection.

\section{DISCUSSIONS}

Findings in this study is consistent with previous studies and showcases that much of the divide between what girls and women knew as 'HIV prevention behavior' and what they actually have the power to do is rooted in gender inequality. A possible direct correlation was lack of consistent condom use, lack of sexual autonomy and higher domestic violence women and coercive sex, seemed to emerge, especially in North eastern and certain northern and Southern States. Analysis of the three models showed that place of residence play a critical role and urban women are at higher risk of contracting HIV. Literature from developing countries illustrate a strong, positive relationship between socioeconomic status and HIV (Shelton 2005), with increased urbanization as an important factor for the spread of HIV (Garnett, et. al., 2001). Similar results have been shown by Over (2001) \& The World Bank (2007, 2011), reiterates that gender inequality in literacy rates and access to work, together with poverty and income inequality, catalyze spread of HIV. Furthermore, gaps in knowledge were likely to be even more pronounced among rural, poor, and uneducated women (Balk et.al., 1997). Evidence presented on condom use was conclusive in India reiterating that within marriage, condoms were largely used for contraceptive 
purposes and seldom for HIV prevention. (Shisana et.al. 2004; Santhya et.al. 2007). Studies also found that 68 percent Indian woman of childbearing age reported rare or no use of condoms with partners, particularly if they were poor and living in rural areas (Solomon et al., 1998; Segal, 1999).

Prevalence of HIV was lower among women with higher ages in all three models, most prevalent among 30-34 age group showing the highest vulnerability. This revealed that maturity with age averted HIV risk taking behavior and HIV outcomes thereof. Other studies corroborated to this finding that early marriage as significantly associated with early age at sterilization and lower condom use and heightened risk for HIV and other STIs (Bhattacharya, 2004; Santhya et. al., 2007; Raj et. al., 2009,). However findings with NFHS-3 dataset, where three-fifths of the women were married before they were 18 years old, did not find a correlation of age at marriage with HIV infection (Ghosh et.al, 2011).

Results from this study reiterated that women with alcoholic husbands were at higher risk to contract HIV, though; both women's empowerment and domestic violence does not show any significant impact on women's HIV status. Other in country studies among men who attended Sexually Transmitted Diseases (STD) clinics showed that alcoholism, indulging in riskier sexual behaviors and extramarital sex were correlated (Saggurti et. al., 2008). Under the influence of alcohol, a man was more likely to forget to use a condom or not to use it properly or was disinclined to use it leading to risky sexual behaviors among the couple (Sivaram et. al.2006; Schensul et. al., 2006).

Our study showed no wealth patterning and the risk of contracting HIV and suggested a more clustered distribution of HIV risk, amongst the wealthiest and poorest sections. Previous literature from NFHS-3 data reveals similar mixed findings of poverty as significantly associated with HIV infection among women to a relatively inconsistent relationship between household wealth and individual HIV status (Ghosh, 2011).

Number of sexual partners emerged as the most important factor which significantly affected HIV status among the women. Women with multiple partners were exposed to a much elevated risk of contracting HIV compared to those who were monogamous. Our study did not show women's empowerment having any influence on HIV status, though husband's alcoholism and exposure to domestic violence had a significant impact on HIV outcome. Previous studies on factors of empowerment like formal education, HIV related knowledge and women's exposure to domestic violence showed complex and mixed bearing with HIV outcomes among women. (World Bank, 1997). However there is lacunae of research on the correlation between the levels of educational attainment and HIV prevalence rates focusing on establishing a causal link between the two (De Walque, 2002). Other studies highlighted, that s bettereducated girls delayed their sexual debut and secondary school educated girls were 24 percent less likely to be sexually experienced at age 18 than those with primary school education (UNAIDS, 2000).

On gender-based violence and HIV, evidence opine that they are twin pandemics that feed into and off each other, with violence being both a cause and a consequence of HIV (Maman et al, 2002). Numerous studies from both developing and developed countries have shown that women with histories of physical abuse, sexual coercion, and rape had higher rates of HIV (Irwin et al., 1995; van der Straten et.al.1995; Wingood et.al.1998; Kimerling et.al.1999; Wyatt et al., 2002; Dunkle et. al. 2004;). Studies also indicated that elevated rates of unsafe sex (e.g. extramarital sex, multiple sex partners, non-use or inconsistent condom use, and forced unprotected sex) were significantly higher among abusive men than non-abusive men (Martin et. al. 1999; Schensul et. al. 2006). Global and the country level literature showed-cases that violence and the threat of it, limited women's ability to protect herself and risked violence if she insisted protection (UNAIDS, UNFPA and UNIFEM, 2004).

Studies from South India (Go et al. 2003), Brazil (Goldstein, 1994), South Africa (Karim, 2011), and the United States (Wingood et.al.1997) similarly highlighted the difficulties of negotiating condom use 
among abused women. Married women were more likely to face violence if they requested their husbands to use condoms, as it is often seen as an admission of marital infidelity (Go et al. 2003; Pallikadavath et.al. 2006). Domestic violence increased HIV risk by limiting a woman's ability to discuss marital infidelity, negotiate condom use, and refuse sexual intercourse (Go et al., 2003). Analysis of various incountry studies suggested that HIV prevalence was four times higher among married women who experienced both physical and sexual violence by their intimate partners than women who were not abused (Silverman et. al., 2008), abusive men were almost twice as likely to acquire HIV outside their marital relationships and placed their wives at greater risk for HIV by an estimated seven times (Decker et. al., 2009) and intimate partner violence was more common in relationships where husbands hade extramarital sex and STI-like symptoms and other sexual problems (Gangakhedkar et. al., 1997; Martin et. al., 1999).

The cross-sectional nature of the data was a limitation to our study which did not allow examination of causal effects. It could not be established whether and how much the contextual and socioeconomic factors caused HIV and risk taking behaviors. Also, for HIV-positive women, the infection might have preceded their marriage or even sexual and other behaviors recorded in the survey. The unclear chronology of events may have biased some of the associations. The strength and direction of the relationship between behavioral and contextual factors and HIV risk taking behavior and the roles of risk behaviors and protective factors are likely to change over time, depending on the age of the woman, duration of marriage, changing inter-spousal relationship, stage and spread of the epidemic, changes in HIV prevention messaging and awareness levels, which the study has not captured. Also aspects of misreporting on sensitive aspects like sexual debut, intimate partner relationships and recall error cannot be ignored.

\section{Conclusion}

In the face of increasing vulnerability of married women to HIV, high unmet need of condoms, prevalence of domestic and sexual violence and alcoholism among male partners within marriage, it is urgent to consider on patterning, and determinants of HIV among married women in India. Although there is a relatively inconsistent relationship between household wealth and individual HIV status, the association between state economic development and individual risk for HIV is intriguing and requires further scrutiny. Further research and analysis on each level of formal education and married women's contracting HIV is pertinent. The study confirms the increased risk for HIV infection among women experiencing sexual violence from their husbands and calls for more granulated understanding of various forms of domestic, intimate partner and sexual violence and the extent to which it impacts HIV vulnerability status and HIV outcomes among married women in India.

\section{REFERENCES}

1. UNAIDS / UNFPA / UNIFEM (2004). ; Women and HIV/AIDS: Confronting the Crisis(1) A Joint Report: $81-8$

2. Basu I, Jana S, Rotheram-Borus MJ, Swendeman D, Lee SJ, Newman P, (2004) HIV prevention among sex workers in India; Journal of Acquired Immune Deficiency Syndromes 36(3):845-852

3. Balk D and Lahiri S. (1997) Awareness and knowledge of AIDS among Indian women: evidence from 13 states; Health Transition Review: The Cultural, Social, and Behavioural Determinants Of Health. Suppl..421-65

4. Bhatia, J, Cleeland, J (1995) Self-reported symptoms of gynecological morbidity and their treatment in South India; Studies in Family Planning, 26(4), 203-245 
5. Bhattacharya G (2004) Sociocultural and behavioural contexts of condom use in heterosexual married couples in India: challenges to the HIV prevention program; Health Education \& Behavior $31: 101-17$

6. Chatterjee, N, Hosain, G.M. (2006); Perceptions of risk and behavior change for prevention of HIV among married women in Mumbai, India; Journal of Health Population Nutrition, 24(1): 81-8

7. Dunkle KL, Jewkes RK, Brown HC, Gray GE, McIntyre JA, Harlow S. (2004) Gender based violence, relationship power, and risk of HIV infection in women attending antenatal clinics in South Africa; The Lancet.; 363:1415-1421

8. Gangakhedkar RR. Bentley ME. Divekar AD (1997) Spread of HIV infection in married monogamous women in India; JAMA; 278:2090-2092

9. Garg, S., Sharma, N., Bhalla, P., Sahay, R., Saha, R., Raina, U. (2002) Reproductive morbidity in an Indian urban slum: need for health action. Sexually Transmitted Infections; 78(1), 68-69

10. Garnett GP, Grassly NC, Gregson S; (2001) The makings of a development disaster? Journal of International Development; Vol:13, ISSN:0954-1748, Pages:391-409

11. George Annie (1998); Differential Perspectives of Men and Women in Mumbai,India on Sexual Relations and Negotiations within Marriage; Reproductive Health Matters, 6(12): 87-96

12. Ghosh P ( 2011) Factors associated with HIV infection among Indian women, International Journal of STD \& AIDS, , 22(3):140-145

13. Go V.F (2003) Crossing the threshold: engendered definitions of socially acceptable domestic violence in Chennai, India; Culture, Health and Sexuality; 5(5): 393-408

14. Hawkes,S , Santhya,K.G. (2002) Diverse realities: sexually transmitted infections and HIV in India; Sexually Transmitted Infections 78, I31-I39 Suppl.

15. HIV Sentinel Surveillance and HIV Estimation in India. 2007 http://www.nacoonline.org/upload/Publication/M\&E\%20Surveillance,\%20Research/HIV \%20Sentinel\%20Surveillance\%20and\%20HIV\%20Estimation\%202007 A\%20Technical\%20Brief.pd $f$

16. ICW, (2001,) ICW News Issue 19, London: ICW; ICW, 2000, ICW News Issue 15, London: ICW

17. Jejeebhoy, S.J. (1998) Wife-Beating in Rural India: A Husband's Right? Evidence From Survey Data; Economic and Political Weekly 33:855-62.

18. Jejeebhoy, Cook (1997); State accountability for wife-beating: The Indian challenge; Lancet 349 $\underline{\text { Suppl }}$

19. Joint United Nations Programme on HIV/AIDS (UNAIDS) (2010) Report On the Global Aids Epidemic; http://www.usaid.gov/our_work/global_health/aids/Countries/asia/india_profile.pdf

20. Kambo, I. P., Dhillon, B. S., Singh, P., \& Saxena, B. N. (2004) Self-reported gynecological problems from twenty three districts of India (ICMR task force study); Indian Journal of Community Medicine, 29(1) 8 
21. Karim A, Kharsany ABM, Naidoo K, Yende N, Gengiah T, Omar Z (2011) Co-enrollment in multiple HIV prevention trials: Experiences from the CAPRISA 004 Tenofovir gel trial. Contemp Clin Trials. in press

22. Kimerling R, Calhoun KS, Forehand R, Armistead L, Morse E, Morse P, Clark R, Clark L. (1999)Traumatic stress in HIV-infected women. AIDS Education and Prevention. ;11:321-330

23. Koenig, M., Jejeebhoy, S., Singh, S., \& Sridhar, S. (1998). Investigating women's gynaecological morbidity in India: Not just another KAP survey. Reproductive Health Matters, 6(11), 84-95

24. Koenig MA, Lutalo T, Zhao F, Nalugoda F, Kiwanuka N, Wabwire-Mangen F; (2004) Coercive sex in rural Uganda: prevalence and associated risk factors; Social Science \& Medicine; 58(4):787-798

25. Mehendale SM Gupte N, Paranjape RS, Brahme RG, Kohli R; Joglekar N, Godbole SV; Ghate MV, Sahay S, Kishore Kumar B, Gangakhedkar RR, Risbud AR, Brookmeyer RS, Bollinger RC (2007); Declining HIV incidence among patients attending sexually transmitted infection clinics in Pune, India; JAIDS Journal of Acquired Immune Deficiency Syndromes 564-9

26. Maman S, Campbell JC, Sweat MD, Gielen AC (2000) The intersections of HIV and violence: Directions for future research and interventions; Social Science \& Medicine; 2000;50:459-478

27. Maman S, Mbwambo JK, Hogan NM, Kilonzo GP, Campbell JC (2002) HIV-positive women report more lifetime partner violence: findings from a voluntary counseling and testing clinic in Dar es Salaam, Tanzania; American Journal of Public Health 92: 1331-1337

28. Mane, P, Rao Gupta G, Weiss E (1994) Effective Communication between partners: AIDS and risk reduction for women; Journal of AIDS, 8(Suppl 1):S325-31

29. Martin SL, Kilgallen B, Tsui AO, Maitra K, Singh KK, Kupper LL (1999); Sexual behaviors and reproductive health outcomes: associations with wife abuse in India; JAMA. 282(20): 1967-72

30. International Institute for Population Sciences (IIPS) and Macro International MD National Family Health Survey (NFHS-3), 2005-06: India. I. Mumbai: IIPS (2007): MEASURE DHS, ORC Macro

31. National AIDS Control Organisation, Ministry Of Health And Family Welfare Government Of India, Annual Report, 2012-2013 http://www.naco.gov.in/upload/Publication/Annual\%20Report/Annual\%20report\%20201213_English.pdf

32. National AIDS Control Organisation, MoHFW, GOI. (2006a). National AIDS Control Program Phase III (2006-2011) Strategy and Implementation Plan. New Delhi: NACO

33. National AIDS Control Organization , Ministry Of Health And Family Welfare Government Of India; (2008); HIV Sentinel Surveillance and HIV Estimation in India 2007, A Technical Brief

34. National AIDS Control Organisation and UNICEF (2000); Feasibility Study Of Administering ShortTerm AZT Intervention Among HIV-Infected Mothers To Prevent Mother-To-Child Transmission of HIV. New Delhi; India: Ministry of Health and Family Welfare 
35. NACO (2004b) Findings of behavioural surveillance surveys (BSS) - general and high risk groups http://www.naco.nic.in/indianscene/bss

36. National AIDS Control Organization(2004). Annual report 2001-2004 http://www.nacoonline.org/annualreport/ annulareport.pdf

37. Newmann S, Sarin P, Kumarasamy N, Amalraj E, Rogers M, Madhivanan P (2000); Marriage, monogamy and HIV: a profile of HIV-infected women in south India; Int J STD AIDS; 11:250-3.

38. Newmann S, Sarin P (2006); Marriage, monogamy and HIV: a profile of HIV-infected women in south India. Int J STD AIDS; 11:250-3

39. Oomman, N. (2000); A decade of research on reproductive tract infections and other gynaecological morbidity in India: What we know and what we don't know. R. Ramasubban \& S. J. Jejeebhoy (Eds.); Women's reproductive health in India (pp. 236-271). New Delhi: Rawat Publications

40. Over, M (2001); The effects of societal variables on urban rates of HIV infection in developing countries: An exploratory analysis. Confronting AIDS: Evidence from the Developing World; ed Martha Ainsworth, Lieve Fransen and Mead Over

41. Pallikadavath S. Sreedharan C. Stones RW (2006); Source of AIDS awareness among women in India; AIDS Care; 18:44-48

42. Population Council, UNAIDS, (2009); HIV Transmission in Intimate Partner Relationships in India

43. Prasad JH, George V, Lalitha, MK, Jayapaul MR, Abraham S, Shetty N (1999) Prevalence of reproductive tract infections among adolescents in Tamil Nadu; Unpublished manuscript.

44. Rao V (1997); Wife-Beating in Rural South India: A Qualitative and Econometric Analysis; Social Science and Medicine 44:1169-80.

45. Raj A, Saggurti N, Balaiah D, Silverman JG (2009); Prevalence of child marriage and its impact on the fertility and fertility control behaviors of young women in India; Lancet

46. Reynolds SJ, Risbud AR, Shepherd ME, Rompalo AM, Ghate MV, Godbole SV, Joshi SN, Divekar AD, Gangakhedkar RR, Bollinger RC, Mehendale SM (2006) High rates of syphilis among STI patients are contributing to the spread of HIV-1 in India Sexually Transmitted Infections, 82(2): 1216

47. Rodrigues JJ, Mehendale SM, Shepherd ME, Divekar AD, Gangakhedkar RR, Quinn TC, Paranjape RS, Risbud AR, Brookmeyer RS, Gadkari DA, et. al.(1995); Risk factors for HIV infection in people attending clinics for sexually transmitted diseases in India; British Medical Journal, 311: 283-6

48. Rogers A et.al.(2006); HIV-Related Knowledge, Attitudes, Perceived Benefits, and Risks of HIV Testing Among Pregnant Women in Rural Southern India;. AIDS Patient Care and STDs Vol 20, No11

49. Santhya, K.G. and Shireen J. Jejeebhoy. (2007); Early marriage and HIV/AIDS: Risk factors among young women in India Economic and Political Weekly 42(14): Soc Sci Med. 2000 Feb;50(4):459-78 
50. Saggurti N, Schensul SL, Verma RK (2009); Migration, mobility and sexual risk behavior in Mumbai, India: mobile men with non-residential wife show increased risk; AIDS Behav 13: 921-927

51. Schensul SL, Mekki-Berrada A, Nastasi BK, Singh R, Burleson JA, Bojko M. (2006); Men's extramarital sex, marital relationships and sexual risk in urban poor communities in India'. Journal of Urban Health; 83(4): 614-24

52. Segal, M. W., Segal, D. R., Bachman, J. G., Freedman-Doan, P., \& O'Malley, P. M. (1998); Gender and the propensity to enlist in the U.S. military; Gender Issues, 16, 65-87

53. Shisana, O, N Zungu-Dirwayi, Y Toefy, L C Simbayi, S Malik, \& K Zuma (2004); Marital status and risk of HIV infection in South Africa; South African Medical Journal (Online); 94.7: 537

54. Shelton JD, Cassell MM, Adetunji J (2005); Is poverty or wealth at the root of HIV? Lancet 366 : $1057-1058$.

55. Silverman J, Decker M (2008); Intimate partner violence and HIV infection among married Indian women; J Am Med Assoc;300:703-10

56. Sivaram S, Latkin CA, Solomon S, Celentano DD (2006); HIV Prevention in India: Focus on Men, Alcohol Use and Social Network; Harvard Health Policy Review, 7(2): 125-134

57. Solomon L, Stein M, Flynn C, Schuman P, Schoenbaum E, Moore J, Holmberg S \& Graham NM (1998); Health services use by urban women with or at risk for HIV-1 infection: The HIV Epidemiology Research Study (HERS); Journal of Acquired Immune Deficiency Syndrome and Retrovirology;17(3), 253-361

58. Srikanth P John et al., (1997) Epidemiological features of acquired immunodeficiency syndrome in Southern India; Indian journal of Medical Research 105, p191-197

59. Solomon S, Kumarasamy N, Ganesh AK, R., Amalraj E (1998); Prevalence and risk factors of HIV-1 and HIV-2 infection in urban and rural areas in Tamilnadu, India. Int. J STD \& AIDS; 9: 98-103

60. The World Bank (2011- 2013); Applying Gender Action Plan Lessons: A Three-Year Road Map for Gender Mainstreaming

61. UNAIDS (2008); Report on the global AIDS epidemic; Joint United Nations Program on HIV/AIDS. Geneva: UNAIDS

http://www.unaids.org/en/Knowledge

Centre/HIVData/GlobalReport/2008/2008_Global_report.asp

62. UNAIDS (2000); (2003) \& (2006); Report on the Global AIDS Epidemic; Joint United Nations Program on HIV/AIDS; Geneva

63. UNDP (2006); Gender Impact of HIV and AIDS in India; New Delhi: NACO/NCAER/UNDP

64. van der Straten A, King R, Grinstead O, Serufilira A, Allen S (1995) Couple communication, sexual coercion and HIV risk reduction in Kigali; Rwanda.(Erratum appears in AIDS 1995 Nov;9(11):following 1298). AIDS 9: 935-944 
65. Weiss HA, Patel V, West B, Peeling RW, Kirkwood BR, Mabey D (2008); Spousal sexual violence and poverty are risk factors for sexually transmitted infections in women: a longitudinal study of women in Goa, India; Sexually Transmitted Infections, 84(2): 133-9

66. Weiss, E., D. Whelan, and G. Rao Gupta (2000); Gender, sexuality and HIV: making a difference in the lives of young women in developing countries; Sexual and Relationship Therapy 15(3): 233-245

67. Wingood GM, DiClemente RJ (1998); Rape among African-American women: sexual, psychological and social correlates predisposing survivors to risk of STD/ HIV; J Womens Health; 1998;7:77-84

68. World Health Organization, Joint United Nations Program on HIV/AIDS, United Nations Children's Fund (2011); Towards Universal Access: Scaling up Priority HIV/AIDS Interventions in the Health Sector Progress report

69. World Health Organization (2006); Burden and socioeconomic impact of alcohol: The Bangalore study; Alcohol Control Series No.1, Department of Non-communicable Disease and Mental Health, World Health Organization. New Delhi: Macro Graphics Pvt. Ltd. 


\section{$\underline{\text { Tables Section }}$}

Table-1: Women's empowerment indicators and HIV Knowledge among currently married women; NFHS-3 (2005-06)

\begin{tabular}{|c|c|c|c|c|c|c|c|c|c|c|c|}
\hline \multirow[b]{2}{*}{ State } & \multirow{2}{*}{$\begin{array}{l}\text { HIV } \\
\text { positive } \\
\text { women } \\
(\%)\end{array}$} & \multirow{2}{*}{$\begin{array}{l}\text { Women } \\
\text { who are } \\
\text { empowered } \\
(\%)\end{array}$} & \multirow[b]{2}{*}{$\begin{array}{l}\text { Women } \\
\text { who } \\
\text { reported } \\
\text { consistent } \\
\text { condom } \\
\text { use }(\%)\end{array}$} & \multirow[b]{2}{*}{$\begin{array}{l}\text { Women } \\
\text { having } \\
\text { sexual } \\
\text { rights } \\
(\%)\end{array}$} & \multirow[b]{2}{*}{$\begin{array}{l}\text { Women } \\
\text { reported } \\
\text { domestic } \\
\text { violence } \\
(\%)\end{array}$} & \multirow{2}{*}{$\begin{array}{l}\text { Women } \\
\text { reported } \\
\text { forced } \\
\text { sex }(\%)\end{array}$} & \multirow[b]{2}{*}{$\begin{array}{l}\text { Women } \\
\text { reported } \\
\text { having } \\
\text { alcoholic } \\
\text { partner } \\
(\%)\end{array}$} & \multicolumn{4}{|c|}{ Comprehensive Knowledge on HIV } \\
\hline & & & & & & & & $\begin{array}{l}\text { No } \\
\text { knowledge }\end{array}$ & $\begin{array}{l}\text { Low } \\
\text { knowledge }\end{array}$ & $\begin{array}{l}\text { Medium } \\
\text { knowledge }\end{array}$ & $\begin{array}{l}\text { High } \\
\text { knowledge }\end{array}$ \\
\hline $\begin{array}{ll}\text { Jammu } & \& \\
\text { Kashmir } & \end{array}$ & 0.30 & 34.1 & 8.7 & 88.6 & 8.1 & 0.0 & 14.0 & 49.4 & 36.2 & 14.4 & 0.0 \\
\hline Himachal Prade & 0.42 & 47.9 & 10.0 & 93.3 & 4.2 & 0.6 & 32.5 & 24.1 & 64.3 & 11.6 & 0.0 \\
\hline Punjab & 0.00 & 62.2 & 16.8 & 93.3 & 14.4 & 1.3 & 48.6 & 33.5 & 50.4 & 15.4 & 0.7 \\
\hline Uttarakhand & 0.00 & 44.4 & 13.4 & 97.1 & 22.5 & 0.9 & 49.1 & 39.4 & 44.3 & 15.6 & 0.7 \\
\hline Haryana & 0.00 & 53.2 & 9.3 & 91.8 & 19.7 & 0.0 & 38.0 & 38.2 & 41.6 & 19.0 & 1.2 \\
\hline Delhi & 0.41 & 58.6 & 18.2 & 91.3 & 10.0 & 0.6 & 32.1 & 16.5 & 44.0 & 37.2 & 2.3 \\
\hline Rajasthan & 0.18 & 41.9 & 4.9 & 91.3 & 28.5 & 6.6 & 23.0 & 71.2 & 17.0 & 11.6 & 0.2 \\
\hline Uttar Pradesh & 0.03 & 41.9 & 6.9 & 96.0 & 30.6 & 3.1 & 26.7 & 64.0 & 24.1 & 11.6 & 0.3 \\
\hline Bihar & 0.00 & 40.0 & 3.5 & 93.3 & 39.8 & 1.2 & 41.4 & 69.2 & 18.4 & 11.9 & 0.5 \\
\hline Sikkim & 0.00 & 65.2 & 4.3 & 95.1 & 13.0 & 0.0 & 44.4 & 39.1 & 39.1 & 21.7 & 0.0 \\
\hline $\begin{array}{l}\text { Arunachal } \\
\text { Pradesh }\end{array}$ & 0.00 & 70.7 & 0.0 & 88.1 & 31.7 & 2.9 & 64.7 & 63.4 & 29.3 & 7.3 & 0.0 \\
\hline Manipur & 1.43 & 84.3 & 1.4 & 94.2 & 31.4 & 1.9 & 61.1 & 7.2 & 33.3 & 59.4 & 0.0 \\
\hline Mizoram & 0.00 & 66.7 & 0.0 & 93.3 & 16.7 & 4.3 & 39.1 & 23.3 & 63.3 & 13.3 & 0.0 \\
\hline Tripura & 0.00 & 50.6 & 1.9 & 76.2 & 28.8 & 4.9 & 41.5 & 40.3 & 44.0 & 15.1 & 0.6 \\
\hline Meghalaya & 0.00 & 32.9 & 5.1 & 78.5 & 11.2 & 1.5 & 49.3 & 73.8 & 22.5 & 3.8 & 0.0 \\
\hline Assam & 0.40 & 26.7 & 1.6 & 87.5 & 31.5 & 3.4 & 38.7 & 59.0 & 32.2 & 7.8 & 0.1 \\
\hline West Bengal & 0.00 & 53.0 & 3.2 & 83.9 & 25.3 & 2.3 & 25.3 & 54.1 & 29.2 & 15.6 & 1.0 \\
\hline Jharkhand & 0.00 & 35.6 & 0.7 & 95.6 & 26.5 & 1.4 & 48.3 & 71.2 & 19.8 & 9.0 & 0.0 \\
\hline Orissa & 0.13 & 49.4 & 1.6 & 88.1 & 23.6 & 2.8 & 38.3 & 49.7 & 29.7 & 20.5 & 0.1 \\
\hline Chhattisgarh & 0.13 & 50.1 & 2.1 & 94.8 & 22.5 & 2.4 & 60.0 & 61.5 & 25.1 & 12.6 & 0.8 \\
\hline Madhya Prades & 0.20 & 43.8 & 5.5 & 96.7 & 33.7 & 4.8 & 32.6 & 55.2 & 21.7 & 22.3 & 0.8 \\
\hline Gujarat & 0.22 & 63.8 & 3.6 & 86.9 & 19.8 & 1.6 & 12.5 & 52.0 & 24.0 & 21.5 & 2.4 \\
\hline Maharashtra & 0.43 & 57.5 & 4.5 & 81.1 & 23.2 & 0.2 & 27.8 & 30.9 & 43.5 & 25.1 & 0.5 \\
\hline
\end{tabular}


IRA-International Journal of Education \& Multidisciplinary Studies

\begin{tabular}{|l|l|l|l|l|l|l|l|l|l|l|l|}
\hline Andhra Pradesh & 0.50 & 39.6 & 0.4 & 80.5 & 27.3 & 0.7 & 49.9 & 38.1 & 37.5 & 23.7 & 0.7 \\
\hline Karnataka & 0.44 & 44.3 & 1.4 & 85.7 & 13.6 & 0.2 & 31.1 & 43.8 & 33.7 & 21.2 & 1.4 \\
\hline Goa & 0.00 & 62.7 & 4.0 & 88.2 & 10.0 & 0.0 & 35.1 & 28.0 & 40.0 & 32.0 & 0.0 \\
\hline Kerala & 0.00 & 49.0 & 2.7 & 84.6 & 12.1 & 0.9 & 42.6 & 13.2 & 45.0 & 41.8 & 0.0 \\
\hline Tamil Nadu & 0.31 & 67.6 & 1.6 & 88.9 & 34.5 & 0.1 & 39.6 & 22.8 & 50.9 & 26.0 & 0.4 \\
\hline Total & $\mathbf{0 . 1 9}$ & $\mathbf{4 7 . 8}$ & $\mathbf{4 . 3}$ & $\mathbf{8 9 . 2}$ & $\mathbf{2 6 . 3}$ & $\mathbf{2 . 8}$ & $\mathbf{3 4 . 0}$ & $\mathbf{4 9 . 5}$ & $\mathbf{3 1 . 3}$ & $\mathbf{1 8 . 5}$ & $\mathbf{0 . 7}$ \\
\hline
\end{tabular}

Source: Computed from NFHS-3 data files.

\section{Comprehensive knowledge of HIV}

$0=$ No knowledge,

$1=$ Low Knowledge = knowing anything between 1-6 ways to prevent or spreading HIV,

2=Medium Knowledge $=$ knowing anything between 7-14 ways to prevent or spreading HIV and

$3=$ High Knowledge $=$ knowing 15 and above ways to prevent or spreading HIV

\section{Table-2: HIV Prevalence among currently married women with background characteristics; NFHS-3 (2005-06)}

\begin{tabular}{|c|c|c|}
\hline Background characteristics & No. of women & Women having HIV (\%) \\
\hline \multicolumn{3}{|l|}{ Residence $* *$} \\
\hline Rural & 27648 & 0.10 \\
\hline Urban & 12254 & 0.30 \\
\hline \multicolumn{3}{|l|}{ Religion* } \\
\hline Hindu & 32380 & 0.20 \\
\hline Muslim & 5278 & 0.00 \\
\hline Christian \& others & 2243 & 0.10 \\
\hline \multicolumn{3}{|l|}{ Ethnicity* } \\
\hline Non SC/ST/OBC & 15359 & 0.20 \\
\hline Scheduled Caste & 9056 & 0.30 \\
\hline Scheduled Tribe & 4243 & 0.20 \\
\hline Other backward castes & 21037 & 0.20 \\
\hline \multicolumn{3}{|c|}{ Educational level (Years of Schooling) } \\
\hline Illiterate/ No schooling & 18465 & 0.20 \\
\hline $0-5$ & 6407 & 0.30 \\
\hline $6-10$ & 12606 & 0.20 \\
\hline $11+$ & 2422 & 0.00 \\
\hline
\end{tabular}


IRA-International Journal of Education \& Multidisciplinary Studies

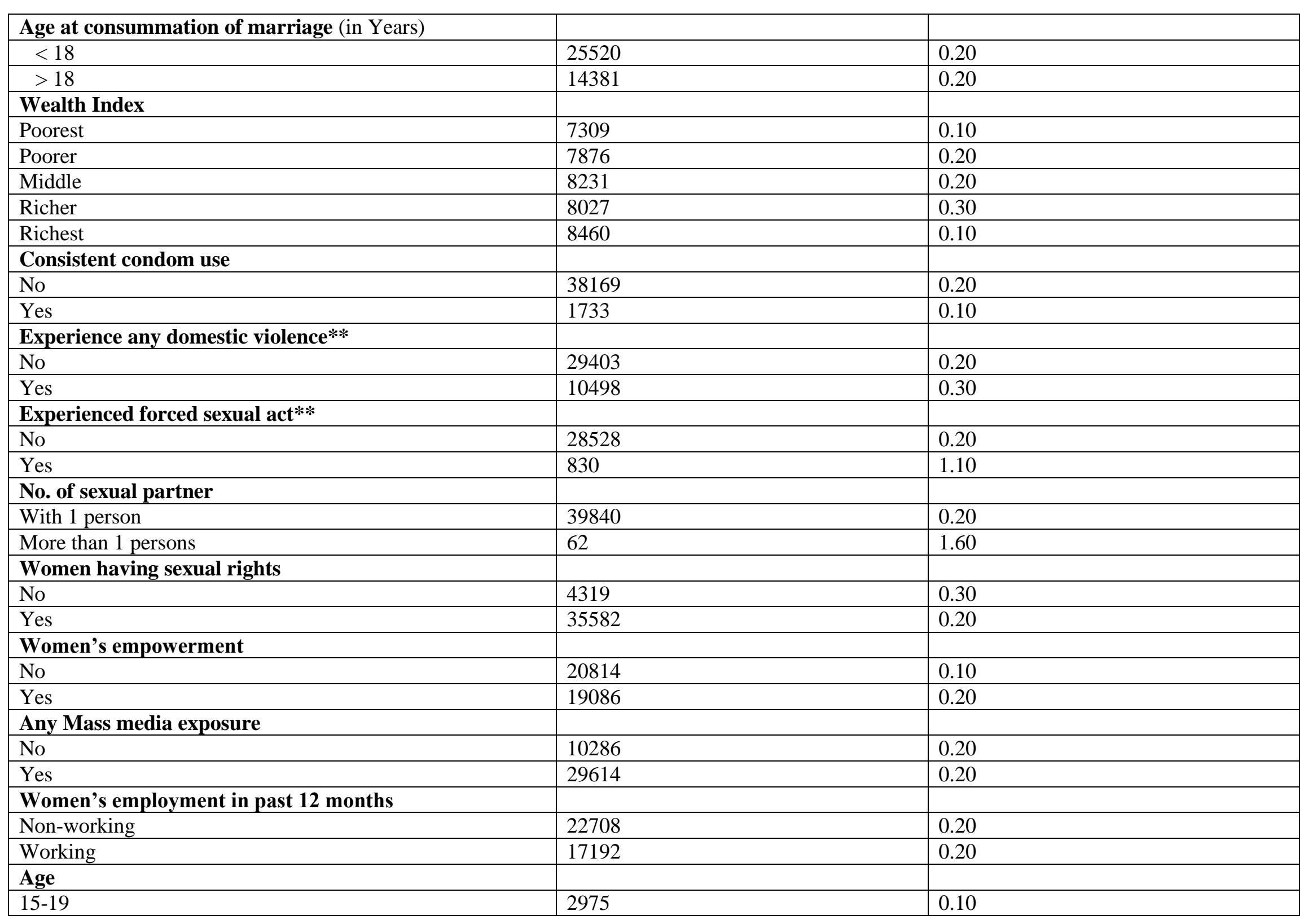


IRA-International Journal of Education \& Multidisciplinary Studies

\begin{tabular}{|l|l|l|}
\hline $20-24$ & 7092 & 0.20 \\
\hline $25-29$ & 8006 & 0.20 \\
\hline $30-34$ & 7181 & 0.30 \\
\hline $35-39$ & 6247 & 0.20 \\
\hline $40-44$ & 4830 & 0.10 \\
\hline $45-49$ & 3570 & 0.10 \\
\hline Comprehensive HIV knowledge** & & \\
\hline No & 19744 & 0.10 \\
\hline Low & 12501 & 0.30 \\
\hline Medium & 7392 & 0.20 \\
\hline High & 264 & 0.00 \\
\hline Male out migration & & \\
\hline State with low male out migration & 22206 & 0.20 \\
\hline States with high male out migration & 17695 & 0.10 \\
\hline Partner drinks alcohol* & & \\
\hline No & 19413 & 0.10 \\
\hline Yes & 9982 & 0.40 \\
\hline Number of women & $\mathbf{3 9 9 0 1}$ & $\mathbf{0 . 2 0}$ \\
\hline
\end{tabular}

Source: Computed from NFHS-3 data files.

Note: For some of the factors, the numbers in categories may not add up to total due to missing information. * Significant at 5 percent level, ** significant at 1 percent level.

Table-3: Comprehensive knowledge of HIV among currently married women by background characteristics; NFHS-3 (2005-06)

\begin{tabular}{|l|l|l|l|l|}
\hline Background characteristics & \multicolumn{2}{l|}{ Comprehensive knowledge of HIV } \\
\cline { 2 - 6 } & No knowledge & low & medium & high \\
\hline Residence ** & & & & \\
\hline Rural & 59.7 & 27.3 & 12.8 & 0.2 \\
\hline Urban & 26.4 & 40.5 & 31.5 & 1.6 \\
\hline Religion** & & & & \\
\hline Hindu & 49.8 & 31.0 & 18.5 & 0.7 \\
\hline Muslim & 54.6 & 30.6 & 14.5 & 0.2 \\
\hline
\end{tabular}


IRA-International Journal of Education \& Multidisciplinary Studies

\begin{tabular}{|c|c|c|c|c|}
\hline Christian \& others & 33.2 & 37.3 & 28.6 & 0.9 \\
\hline \multicolumn{5}{|l|}{ Ethnicity** } \\
\hline Non SC/ST/OBC & 48.8 & 34.6 & 15.9 & 0.7 \\
\hline Scheduled Caste & 47.4 & 32.4 & 19.5 & 0.7 \\
\hline Scheduled Tribe & 74.9 & 17.1 & 7.7 & 0.3 \\
\hline Other backward castes & 51.3 & 32.0 & 16.2 & 0.0 \\
\hline \multicolumn{5}{|c|}{ Educational level (Years of Schooling)** } \\
\hline Illiterate/ No schooling & 76.0 & 19.4 & 4.6 & 0.0 \\
\hline $0-5$ & 49.2 & 37.1 & 13.4 & 0.2 \\
\hline $6-10$ & 20.0 & 46.2 & 32.8 & 1.0 \\
\hline $11+$ & 1.7 & 29.9 & 63.7 & 4.6 \\
\hline \multicolumn{5}{|c|}{ Age at consummation of marriage (in Years) $* *$} \\
\hline$<18$ & 60.5 & 27.5 & 11.7 & 0.3 \\
\hline$>18$ & 30.0 & 38.1 & 30.6 & 1.3 \\
\hline \multicolumn{5}{|l|}{ Wealth Index $* *$} \\
\hline Poorest & 83.0 & 13.5 & 3.5 & 0.0 \\
\hline Poorer & 69.2 & 23.6 & 7.1 & 0.0 \\
\hline Middle & 52.4 & 34.4 & 13.0 & 0.1 \\
\hline Richer & 33.4 & 41.9 & 24.0 & 0.7 \\
\hline Richest & 14.5 & 40.8 & 42.3 & 2.3 \\
\hline \multicolumn{5}{|c|}{ Experience any domestic violence } \\
\hline No & 45.7 & 32.9 & 20.5 & 0.8 \\
\hline Yes & 59.7 & 26.9 & 13.1 & 0.4 \\
\hline \multicolumn{5}{|c|}{ Experienced forced sexual act** } \\
\hline No & 49.2 & 31.0 & 19.0 & 0.7 \\
\hline Yes & 61.3 & 27.4 & 10.2 & 1.1 \\
\hline \multicolumn{5}{|l|}{ No. of sexual partner } \\
\hline 1 person & 49.5 & 31.4 & 18.5 & 0.7 \\
\hline More than 1 persons & 62.9 & 17.7 & 17.7 & 1.6 \\
\hline \multicolumn{5}{|c|}{ Women having sexual rights $* *$} \\
\hline No & 53.4 & 31.6 & 14.7 & 0.3 \\
\hline Yes & 49.0 & 31.3 & 19.0 & 0.7 \\
\hline \multicolumn{5}{|l|}{ Women empowerment $* *$} \\
\hline No & 53.1 & 29.3 & 17.1 & 0.5 \\
\hline Yes & 45.6 & 33.6 & 20.1 & 0.8 \\
\hline
\end{tabular}


IRA-International Journal of Education \& Multidisciplinary Studies

\begin{tabular}{|c|c|c|c|c|}
\hline \multicolumn{5}{|l|}{ Any Mass media exposure $* *$} \\
\hline No & 86.1 & 11.8 & 2.1 & $\mathbf{0 . 0}$ \\
\hline Yes & 36.7 & 38.1 & 24.2 & 0.9 \\
\hline \multicolumn{5}{|c|}{ Women employment in past 12 months* } \\
\hline Non-working & 42.2 & 35.0 & 22.0 & 0.7 \\
\hline Working & 59.1 & 26.4 & 13.9 & 0.6 \\
\hline \multicolumn{5}{|l|}{$\operatorname{Age}^{* *}$} \\
\hline $15-19$ & 58.5 & 27.7 & 13.7 & 0.1 \\
\hline $20-24$ & 45.5 & 34.0 & 20.0 & 0.5 \\
\hline $25-29$ & 44.8 & 33.2 & 21.0 & 0.9 \\
\hline $30-34$ & 48.8 & 29.9 & 20.5 & 0.8 \\
\hline $35-39$ & 50.6 & 31.0 & 17.8 & 0.6 \\
\hline $40-44$ & 51.3 & 31.6 & 16.3 & 0.8 \\
\hline $45-49$ & 57.1 & 28.0 & 14.5 & 0.4 \\
\hline \multicolumn{5}{|l|}{ Male out migration ** } \\
\hline State with low male out migration & 42.9 & 35.7 & 20.6 & 0.9 \\
\hline States with high male out migration & 57.7 & 25.9 & 16.0 & 0.4 \\
\hline \multicolumn{5}{|l|}{ Partner drinks alcohol** } \\
\hline No & 48.4 & 30.9 & 19.8 & 0.8 \\
\hline Yes & 52.0 & 30.8 & 16.7 & 0.5 \\
\hline Total & 49.5 & 31.3 & $\mathbf{1 8 . 5}$ & $\mathbf{0 . 7}$ \\
\hline
\end{tabular}

Source: Computed from NFHS-3 data files.

Note: * significant at 10 percent level, ** significant at 1 percent level.

No knowledge $=0$,

Low Knowledge $=$ knowing anything between 1-4 ways to prevent or spreading HIV,

Medium Knowledge = knowing anything between 5-8 ways to prevent or spreading HIV and

High Knowledge $=$ knowing 9 and above ways to prevent or spreading HIV. 
Table-4: Multiple Classification Analysis of comprehensive knowledge on HIV by background characteristics among currently married women in India, NFHS-3 (2005-06)

\begin{tabular}{|c|c|c|c|c|c|}
\hline Variables/Categories & $\begin{array}{l}\text { No. of } \\
\text { Women }\end{array}$ & $\begin{array}{l}\text { Mean knowledge on } \\
\text { HIV } \\
\text { ( Unadjusted) }\end{array}$ & Eta & $\begin{array}{l}\text { Mean knowledge on HIV } \\
\text { (Adjusted for Independents and } \\
\text { Covariates) }\end{array}$ & Beta \\
\hline Place of residence & & & 0.305 & & 0.037 \\
\hline Rural & 27648 & 1.408 & & 1.836 & \\
\hline Urban & 12253 & 2.999 & & 2.032 & \\
\hline Religion & & & 0.092 & & 0.110 \\
\hline Hindu & 32380 & 1.890 & & 1.890 & \\
\hline Muslim & 5278 & 1.592 & & 1.889 & \\
\hline Christian \& others & 2243 & 2.700 & & 2.007 & \\
\hline Caste & & & 0.120 & & 0.021 \\
\hline Other than SC/ST/OBC & 15359 & 1.656 & & 1.618 & \\
\hline Scheduled caste & 9056 & 1.986 & & 1.912 & \\
\hline Scheduled tribe & 4243 & 0.866 & & 1.808 & \\
\hline Other backward castes & 21037 & 1.738 & & 1.703 & \\
\hline Educational level (Years of Schooling) & & & 0.564 & & 0.389 \\
\hline Illiterate/ No schooling & 18466 & 0.696 & & 1.096 & \\
\hline $0-5$ & 6407 & 1.636 & & 1.654 & \\
\hline $6-10$ & 12606 & 3.153 & & 2.731 & \\
\hline $11+$ & 2423 & 5.195 & & 4.296 & \\
\hline Wealth Index & & & 0.491 & & 0.194 \\
\hline Poorest & 7308 & 0.490 & & 1.362 & \\
\hline Poorer & 7876 & 0.941 & & 1.479 & \\
\hline Middle & 8231 & 1.550 & & 1.769 & \\
\hline Richer & 8027 & 2.477 & & 2.141 & \\
\hline Richest & 8459 & 3.787 & & 2.632 & \\
\hline Women employment in past 12 months & & & 0.135 & & 0.034 \\
\hline Non-working & 22709 & 2.179 & & 1.825 & \\
\hline Working & 17192 & 1.523 & & 1.991 & \\
\hline Any Mass media exposure & & & 0.373 & & 0.124 \\
\hline No & 10287 & 0.374 & & 1.3899 & \\
\hline Yes & 29614 & 2.425 & & 2.072 & \\
\hline
\end{tabular}


IRA-International Journal of Education \& Multidisciplinary Studies

\begin{tabular}{|l|l|l|l|l|l|}
\hline Experience any domestic violence & & & $\mathbf{0 . 1 1 6}$ & & $\mathbf{0 . 0 1 0}$ \\
\hline No & 29403 & 2.063 & & 1.882 & \\
\hline Yes & 10498 & 1.429 & & 1.937 & \\
\hline Women empowerment & & & $\mathbf{0 . 0 6 5}$ & & \\
\hline No & 20814 & 1.748 & & 1.817 & \\
\hline Yes & 19087 & 2.058 & & 1.983 & \\
\hline Total women $=\mathbf{3 9 9 0 1}$ & Multiple R= 0.610 & & R square $=\mathbf{0 . 3 7 2}$ \\
\hline
\end{tabular}

Source: Computed from NFHS-3 (2005-06) data files.

Note: Analysis includes currently married women

Table-5: Logistics regression Risk of HIV infection among currently married women with background characteristics, NFHS-3 (2005-06)

\begin{tabular}{|c|c|c|c|c|c|c|}
\hline \multirow[t]{2}{*}{ Background characteristics } & \multicolumn{2}{|l|}{ Model 1} & \multicolumn{2}{|l|}{ Model 2} & \multicolumn{2}{|l|}{ Model 3} \\
\hline & Odds ratio & Sig, & Odds ratio & Sig, & Odds ratio & Sig, \\
\hline \multicolumn{7}{|l|}{ Residence } \\
\hline \multicolumn{7}{|l|}{ Rural (RC) } \\
\hline Urban & 1.491 & 0.006 & 1.533 & 0.003 & 1.478 & 0.008 \\
\hline \multicolumn{7}{|l|}{ Religion } \\
\hline \multicolumn{7}{|l|}{ Hindu (RC) } \\
\hline Muslim & 0.570 & 0.322 & 0.484 & 0.197 & 0.577 & 0.322 \\
\hline Christian \& others & 0.685 & 0.568 & 0.778 & 0.704 & 0.677 & 0.557 \\
\hline \multicolumn{7}{|l|}{ Ethnicity } \\
\hline \multicolumn{7}{|l|}{ Non SC/ST/OBC (RC) } \\
\hline Scheduled Caste & 1.283 & 0.004 & 1.478 & 0.003 & 1.493 & 0.003 \\
\hline Scheduled Tribe & 0.742 & 0.313 & 0.629 & 0.745 & 0.644 & 0.139 \\
\hline Other backward castes & 1.043 & 0.956 & 0.968 & 0.254 & 0.945 & 0.051 \\
\hline \multicolumn{7}{|c|}{ Educational level (Years of Schooling) } \\
\hline \multicolumn{7}{|l|}{ Illiterate/ No schooling (RC) } \\
\hline $0-5$ & 2.117 & 0.027 & 2.197 & 0.020 & 0.2117 & 0.027 \\
\hline $6-10$ & 0.730 & 0.339 & 0.733 & 0.344 & 0.732 & 0.342 \\
\hline $11+$ & 0.287 & 0.107 & 0.259 & 0.080 & 0.287 & 0.017 \\
\hline Age at consummation of 1 & & & & & & \\
\hline
\end{tabular}


IRA-International Journal of Education \& Multidisciplinary Studies

\begin{tabular}{|c|c|c|c|c|c|c|}
\hline \multicolumn{7}{|l|}{ Years) } \\
\hline$<18(\mathrm{RC})$ & & & & & & \\
\hline$>18$ & 0.177 & 0.251 & 1.169 & 0.271 & 1.181 & 0.240 \\
\hline \multicolumn{7}{|l|}{ Wealth Index } \\
\hline \multicolumn{7}{|l|}{ Poorest (RC) } \\
\hline Poorer & 1.097 & 0.727 & 1.114 & 0.681 & 1.099 & 0.723 \\
\hline Middle & 0.848 & 0.538 & 0.892 & 0.668 & 0.847 & 0.536 \\
\hline Richer & 1.996 & 0.003 & 1.920 & 0.005 & 1.999 & 0.003 \\
\hline Richest & 1.130 & 0.743 & 1.012 & 0.974 & 1.130 & 0.742 \\
\hline \multicolumn{7}{|c|}{ Consistent condom use } \\
\hline \multicolumn{7}{|l|}{ No $(\mathrm{RC})$} \\
\hline Yes & 0.383 & 0.0136 & 0.43 & 0.154 & 0.380 & 0.134 \\
\hline \multicolumn{7}{|c|}{ Experience any domestic violence } \\
\hline \multicolumn{7}{|l|}{ No (RC) } \\
\hline Yes & 1.017 & 0.903 & - & - & 1.010 & 0.943 \\
\hline \multicolumn{7}{|c|}{ Experienced forced sexual act } \\
\hline \multicolumn{7}{|l|}{ No $(\mathrm{RC})$} \\
\hline Yes & 1.145 & 0.724 & 1.195 & 0.641 & 1.144 & 0.727 \\
\hline \multicolumn{7}{|l|}{ No. of sexual partner } \\
\hline \multicolumn{7}{|l|}{1 person $(\mathrm{RC})$} \\
\hline More than 1 persons & 3.391 & 0.014 & 3.451 & 0.012 & 3.334 & 0.015 \\
\hline \multicolumn{7}{|c|}{ Women having sexual rights } \\
\hline \multicolumn{7}{|c|}{ No (RC) } \\
\hline Yes & 0.924 & 0.678 & 0.944 & 0.763 & 0.922 & 0.671 \\
\hline \multicolumn{7}{|c|}{ Women empowerment } \\
\hline \multicolumn{7}{|l|}{ No (RC) } \\
\hline Yes & - & - & 1.141 & 0.309 & 1.109 & 0.428 \\
\hline \multicolumn{7}{|c|}{ Any Mass media exposure } \\
\hline \multicolumn{7}{|l|}{ No (RC) } \\
\hline Yes & 0.643 & 0.008 & 0.653 & 0.011 & 0.642 & 0.008 \\
\hline \multicolumn{7}{|c|}{ Women employment in past 12 months } \\
\hline \multicolumn{7}{|l|}{ Non-working (RC) } \\
\hline Working & - & - & 1.234 & 0.115 & 1.204 & 0.170 \\
\hline \multicolumn{7}{|l|}{ Age } \\
\hline $15-19(\mathrm{RC})$ & & & & & & \\
\hline
\end{tabular}


IRA-International Journal of Education \& Multidisciplinary Studies

\begin{tabular}{|c|c|c|c|c|c|c|}
\hline $20-24$ & 1.526 & 0.177 & 1.534 & 0.172 & 1.547 & 0.164 \\
\hline $25-29$ & 1.275 & 0.408 & 1.286 & 0.391 & 1.275 & 0.409 \\
\hline $30-34$ & 1.978 & 0.009 & 2.039 & 0.006 & 1.970 & 0.009 \\
\hline $35-39$ & 0.903 & 0.771 & 0.914 & 0.797 & 0.895 & 0.752 \\
\hline $40-44$ & 0.837 & 0.670 & 0.855 & 0.706 & 0.821 & 0.636 \\
\hline $45-49$ & 0.350 & 0.140 & 0.342 & 0.132 & 0.343 & 0.133 \\
\hline \multicolumn{7}{|l|}{ Comprehensive HIV knowledge } \\
\hline \multicolumn{7}{|l|}{ No (RC) } \\
\hline Low & 3.242 & 0.912 & 3.329 & 0.995 & 3.214 & 0.950 \\
\hline Medium & 2.144 & 0.996 & 2.725 & 0.995 & 2.402 & 0.995 \\
\hline High & 1.265 & 0.996 & 1.561 & 0.996 & 1.325 & 0.996 \\
\hline \multicolumn{7}{|l|}{ Male out migration } \\
\hline \multicolumn{7}{|l|}{ State with low male out migration (RC) } \\
\hline States with high male out migration & 0.884 & 0.377 & 0.877 & 0.343 & 0.886 & 0.383 \\
\hline \multicolumn{7}{|l|}{ Partner drinks alcohol } \\
\hline \multicolumn{7}{|l|}{ No (RC) } \\
\hline Yes & 1.499 & 0.002 & - & - & 1.491 & 0.003 \\
\hline$-2 \log$ likelihood & 803.448 & & 812.465 & & 802.814 & \\
\hline Pseudo R square (Nagelkarke) & 0.141 & & 0.131 & & 0.142 & \\
\hline Number of women & 39901 & & & & & \\
\hline
\end{tabular}

Source: Computed from NFHS-3 data files.

Note:

1. NA: Not applicable. RC: Reference category.

2. Model-1: SES \& Domestic violence; Model-2: SES \& women autonomy; Model-3: All 


\section{Appendix}

\section{Definition of some variables}

\begin{tabular}{|c|c|}
\hline Forced sex & Anyone forced respondent to perform sexual act forcibly \\
\hline Consistent condom use & $\begin{array}{l}\text { Used condom every time had sex with last partner } \& \text { also used condom every time had sex with next } \\
\text { to last partner }\end{array}$ \\
\hline Domestic violence & Spouse ever pushed/slapped/punched/kicked \\
\hline Exposed to media & Read/listen/see newspaper/radio/television \\
\hline Sexual right & $\begin{array}{l}\text { Respondent said as Reason for not having sex with partner/husband as husband has STI/having sex } \\
\text { with other women/ respondent feeling tired or not in mood }\end{array}$ \\
\hline Women empowerment & $\begin{array}{l}\text { If any one of them is yes } \\
\text { - Decided to how to spend money } \\
\text { - } \text { Final say on own health care } \\
\text { - Making large HH purchase } \\
\text { - Daily need } \\
\text { - Visit family } \\
\end{array}$ \\
\hline HIV knowledge & $\begin{array}{l}\text { Variables used } \\
\text { - Can get AIDS by hugging } \\
\text { - Way to avoid AIDS as } \\
\text { Abstain from sex } \\
\text { Use condom during sex } \\
\text { Only one partner } \\
\text { Avoid sex with prostitutes } \\
\text { Avoid sex with homosexuals } \\
\text { Avoid blood transfusion }\end{array}$ \\
\hline
\end{tabular}


IRA-International Journal of Education \& Multidisciplinary Studies

\begin{tabular}{|l|l|}
\hline & Avoid injection \\
& Avoid kissing \\
& Avoid mosquito bites \\
& Limit number of sex partners \\
& Avoid partner who has many partners \\
& Avoid having sex with IV drug user \\
& Avoid sharing razor blades with aids patients \\
& Use blood from only relatives \\
& Use only sterilized /new needles \\
& Avoid IV drip \\
& Male teacher with aids virus allowed to continue teaching \\
\hline
\end{tabular}

